\title{
CHITINASE: LOCALIZATION, ACTIVITY PATTERN AND CHANGES AFTER NOMOLT INSECTICIDE TREATMENT IN THE BLACK CUTWORM, AGROTIS IPSILON (HUFN.)
}

\section{AZIZA H. MOHAMADY ${ }^{1 *}$ and TAREK R. AMIN ${ }^{2}$}

1. Bioassay Department, Central Agricultural Pesticides Laboratory, ARC, Dokki, Giza 12618, Egypt.

2. Pest Physiology Department, Plant Protection Research Institute, ARC, Dokki, Giza, Egypt.

*Corresponding author, E-mail address: aziza_1972@yahoo.com

(Manuscript received 15 March 2017)

\begin{abstract}
$\longrightarrow$

hitinase as endo-type of chitinolytic enzymes was studied in the 4th larval instar of the black cutworm, Agrotis ipsilon (Lepidoptera: Noctuidae) to detect some of its physiological aspects. Results showed that, the chitinase activity was low till $18 \mathrm{~h}$ before ecdysis to the 4th instar, but the activity started increasing at $10 \mathrm{~h}$ and reached a peak at $2 \mathrm{~h}$ before the ecdysis. This confirms that the appearance of chitinase activity is restricted to the molting period and the main function of chitinase in larvae is the digestion of old cuticle. On the other hand, the enzyme activity in pupal stage was 1.73 -fold as compared to that present in larvae, might to share in the intensive physiological processes in this stage. Results of enzyme localization revealed that, larval integument had the highest chitinase activity $(72.3 \%)$, while hemolymph had the lowest one (1.9\%). Hence, we infer that hemolymph plays minor role in transporting the enzyme, and chitinase localized there in the integument. The results showed that hyperchitinase activity in larvae was not a sign of $\mathrm{LC}_{50}$ treatment by nomolt. This led to the assumption that nomolt acts by inhibition of chitin synthesis not by enhancing of chitin degradation. Future studies concerned with factors affecting chitinase must take into consideration the fact that larval chitinase activity is rhytmic, i.e. precaution that the sampling time is critical. Keywords: Chitinase, Molting, Localization, Chitin synthesis inhibitors, Agrotis ipsilon.
\end{abstract}

\section{INTRODUCTION}

Chitin is a natural important biopolymer that is mainly produced by fungi, arthropods, and nematodes. It's recognized as the main scaffolding material for supporting the cuticles of the epidermis, trachea, peritrophic membrane and lining the epithelium of the gut in insects (Qu et al., 2014).

One of the insect characteristics is they are enclosed within a relatively inextensible exoskeleton which must be cast intervals to permit growth. To assist in shedding, and presumably to conserve material, the old cuticle prior to its discard is 
thinned by a molting fluid which has long been assumed to possess chitinolytic and proteolytic activity to degrade chitin which is not only the major component of cuticle, but also of other parts of the body (Amin 1998; Merzendorfer \& Zimoch, 2003 and Zhang et al., 2012). Chitinolytic enzymes and their genes have received a great deal of attention. Their chemical and physical regulatory properties, as well as their potential for development as biopesticides or chemical defense proteins in transgenic plants and microbial control agents are being explored (Ghareeb, 2009; Kramer and Muthukrishanan, 1997 and Singh et al., 2014).

Chemical compounds which specifically interfere with chitin deposition offer possibility to develop a group of insecticides known as chitin synthesis inhibitors (CSI's). Since the discovery of this group of insecticides by Philips-Duphar research workers, the biochemical effects of CSI's have received considerable attention. Authors found variable and sometimes conflicting observations (Mayer et al., 1981; Post et al.,1974 and Zhu et al., 2011). Amin (1998) found that classical CSI's such as diflubenzuron activated chitinase of the cotton leafworm only during molting period, and concluded that CSI's do not act by activation of chitinase. Since the time (mid of sixties) of green revolution, utilization of chemical pesticides is considered as reliable and beneficial choice for the inhibition of pests. One of these chemicals is the CSI, nomolt (teflubenzuron) which used to interfere with moulting processes of larvae such as the black cutworm, Agrotis ipsilon that attack vegetables and field crops causing severe damage. The aim of the present topic was to study chitinase of $A$. ipsilon larvae from physiological aspects such as: (1) Chitinase localization (2) Pattern of activity in larvae (3) Presence of chitinase in other stages as pupae (4) Effect of treatment by nomolt insecticide on chitinase activity.

\section{MATERIALS AND METHODS}

\section{Insect used:}

A laboratory strain of the black cutworm, A. ipsilon was obtained from Central Agricultural Pesticide Laboratory (CAPL), Dokki, Giza. Larvae were reared on castor bean leaves under constant conditions of $25 \pm 2^{\circ} \mathrm{C}$ and $65 \pm 5 \%$ R.H, without any exposure to insecticides. Caterpillars that had just molted were used throughout in order to obtain a synchrony in the life cycle till the pupal stage.

\section{Insecticide used:}

Chitin synthesis inhibitor, Nomolt $15 \%$ SC (active ingredient, teflubenzuron) was obtained from Basf limited (Egypt) as formulated compound. 


\section{Toxicity assay:}

Leaf-dipping technique was carried out according to Abo El-Ghar et al. (1994) to determine the median lethal concentration $\left(\mathrm{LC}_{50}\right)$ of nomolt. Serial concentrations of nomolt (45, 70, 100, 185.250, 530 and 700ppm) were prepared in tap water. Freshly collected castor bean leaves were dipped for 20 seconds in each concentration, then were left for one hour to dry. Newly molted $4^{\text {th }}$ instar larvae were confined with treated leaves in glass jars in 5 replicates (10 larvae for each concentration) for $48 \mathrm{~h}$. Treated leaves were then removed and fresh untreated ones were provided. Mortality counts were recorded after $72 \mathrm{~h}$ from treatment, and corrected as compared to control larvae according to Abbott formula (Abbott, 1925). Toxicity value (LC50) was calculated by probit analysis using Ldp-line software according to Finney (1971).

To determine the effect of nomolt insecticide on chitinase activity, larvae treated with $L_{50}$ of nomolt as described before, larvae were starved for $6 \mathrm{~h}$ before use in order to induce an even feeding rate. All insects' assays were in quadruplicate and the results pooled from 2-3 experiments.

\section{Tissue collection:}

Different tissues and whole body (larvae and pupae) were collected as described by Amin (1998). Tissues were rinsed twice with $0.1 \mathrm{M}$ sodium phosphate buffer $(\mathrm{pH}$ 7). Hemolymph was collected in a chilled centrifuge tube containing a trace of phenylthiourea. Then, all tissues were kept at $-20^{\circ} \mathrm{C}$ for subsequent use.

\section{Extraction of enzyme:}

The frozen bodies, integuments, alimentary canal and fat tissues were broken into pieces and homogenized in 10 volumes of phosphate buffer $(\mathrm{pH} 7)$ using electric homogenizer. The homogenate and hemolymph were centrifuged (Beckman, USA) at $11000 \mathrm{rpm}$ for $30 \mathrm{~min}$ at $4^{\circ} \mathrm{C}$. The supernatant was used for chitinase assay.

\section{Chitinase assay:}

The reaction mixture was prepared according to Ishaaya \& Casida (1974). It consisted of $0.12 \mathrm{ml}$ phosphate buffer $(0.2 \mathrm{M}, \mathrm{pH} \mathrm{6.6)}, 0.3 \mathrm{ml} 0.5 \%$ colloidal chitin (Bade \& Stinson, 1981), $0.18 \mathrm{ml}$ enzyme solution. After $60 \mathrm{~min}$ incubation at $37^{\circ} \mathrm{C}$, enzyme activity was terminated by boiling. Undigested chitin was sedimented by centrifugation for $25 \mathrm{~min}$ at $6000 \mathrm{rpm}$. The supernatant was taken for determination of N-acetylglucosamine (NAGA) according to Waterhouse et al. (1961). Double beam ultraviolet/visible spectrophotometer (Milton Roy Co. USA) was used to measure absorbance of NAGA reaction at $540 \mathrm{~nm}$. One unit (U) of chitinase activity was defined as amount of enzyme required to release $1 \mathrm{nmol}$ of NAGA per min from colloidal 
chitin. The specific activity was expressed as units of chitinase activity per milligram of protein (U/ mg of protein).

\section{Statistical analysis:}

Data obtained from the present study are presented as mean \pm standard error (mean $\pm \mathrm{SE}$ ). The significant difference between control and treated larvae was calculated by one-way analysis of variance (ANOVA) at $P<0.01$.

\section{RESULTS AND DISCUSSION}

\section{Appearance of Chitinase:}

Data in Figure 1 shows a decrease in chitinase activity till $18 \mathrm{~h}$ before ecdysis to the $4^{\text {th }}$ instar, but the activity suddenly increased at $10 \mathrm{~h}(42.37 \mathrm{U} / \mathrm{mg}$ of protein) and reached a peak at $2 \mathrm{~h}$ before the ecdysis ( $118.64 \mathrm{U} / \mathrm{mg}$ of protein). After ecdysis, the activity decreased sharply and reached to the lowest level of activity during intermoult period. The activity recorded at $2 \mathrm{~h}$ and $6 \mathrm{~h}$ post-ecdysis was 20.72 and $16.95 \mathrm{U} / \mathrm{mg}$ of protein, respectively.

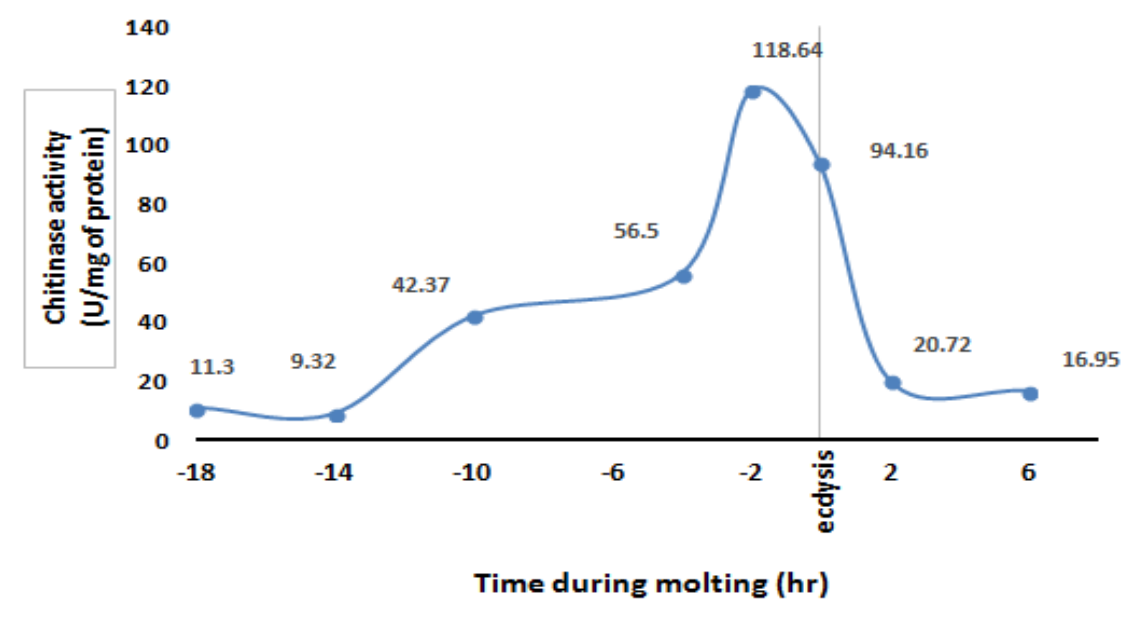

Figure 1 . Chitinase activity of $A$. ipsilon during molting to the $4^{\text {th }}$ larval instar.

On the other hand, chitinase activity that was found in larvae as an important enzyme for successful ecdysis consequently enables larvae to develop, it was also found in pupae in a relatively higher titer than that present in larvae. During pupal stage (4 days old), chitinase activity was $205.03 \mathrm{U} / \mathrm{mg}$ of protein (Figure 2). It was 1.73 fold as compared to larvae during molting to the fourth larval instar. 


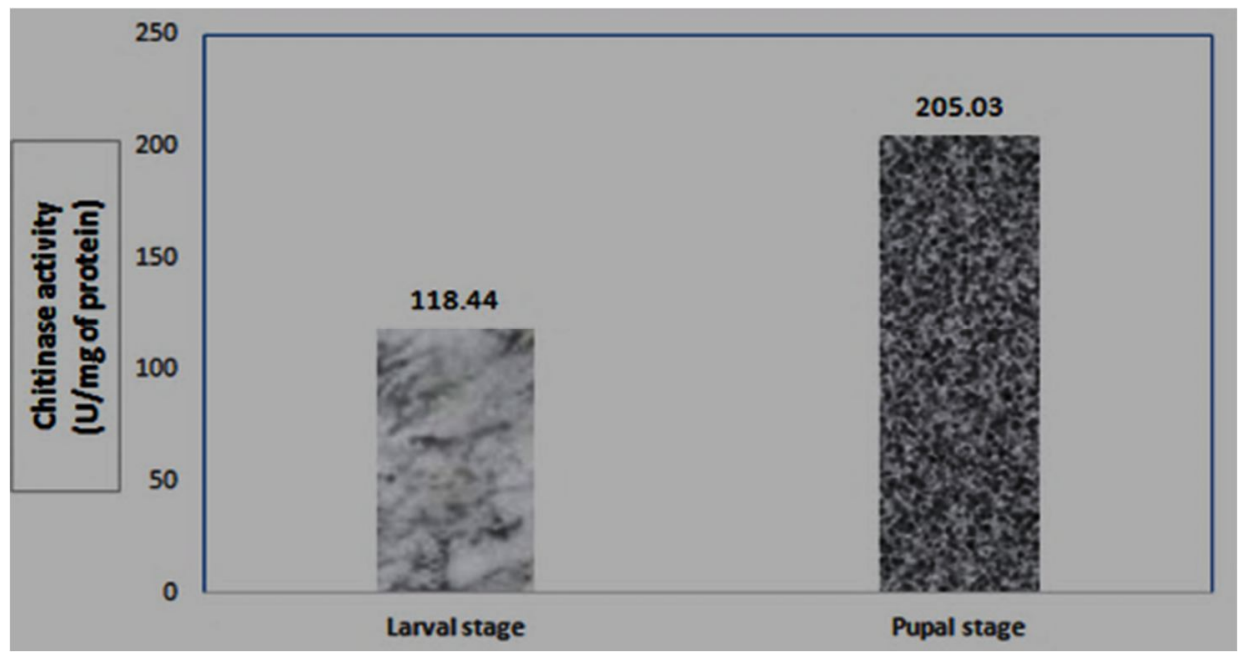

Figure 2. Comparison between A. ipsilon larval and pupal chitinase activity. - larval titer was during molting to the 4th larval instar. pupal titer was during mid-pupal stage (4 days old).

\section{Localization of Chitinase:}

Distribution of chitinase activity in different $A$. ipsilon body tissues during molting to the $4^{\text {th }}$ larval instar is shown in Figure 3 . The data showed that the integument had the highest chitinase activity, while hemolymph had the lowest activity. The enzyme activity in integument represented $72.3 \%$ of the total enzyme activity, while alimentary canal, fat tissues and hemolymph had 18.1, 2.7 and 1.9\% of total activity, respectively. The remaining activity (5\%) of the total enzyme activity might be distributed in other tissues like salivary glands. The data represents values as compared to percentage of total activity.

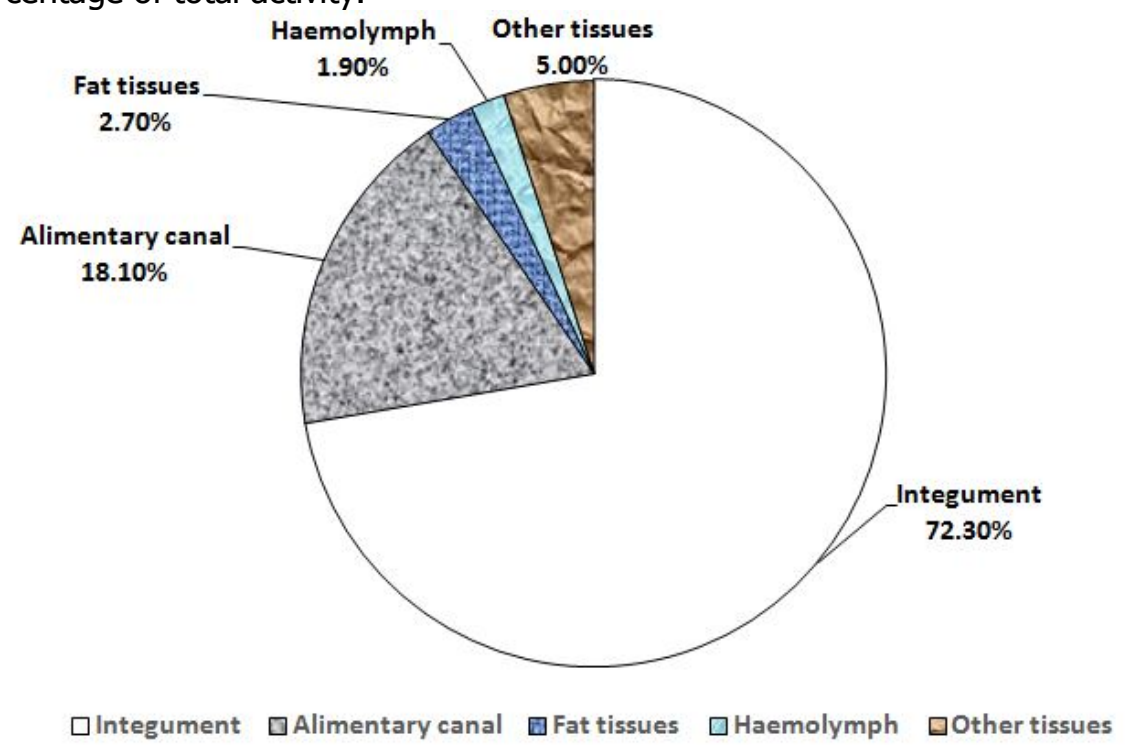

Figure 3. Distribution of chitinase activity in different tissues of $A$. ipsilon larvae during molting to the $4^{\text {th }}$ larval instar. 


\section{Treatment by nomolt and chitinase activity:}

As shown in Figure 4 , the median lethal concentration $\left(L_{50}\right)$ of nomolt was $173.89 \mathrm{ppm}(95 \% \mathrm{CL}=144.09-209.89 \mathrm{ppm}$; slope $=1.8)$ for $4^{\text {th }}$ larval instar of $A$. ipsilon. Chitinase activity in whole body homogenate of treated larvae with LC 50 of nomolt is given in Table (1). Data revealed that treatment by CSI did not enhanced chitinase activity during intermolting or molting period. Chitinase activity during intermolting period was 11.28 and $12.41 \mathrm{U} / \mathrm{mg}$ of protein for control and treated larvae, respectively. While few hours before ecdysis, the enzyme activity was 108.1 and $98.61 \mathrm{U} / \mathrm{mg}$ of protein for control and treated larvae, respectively. The recorded changes were found to be insignificant at $P<0.01$.

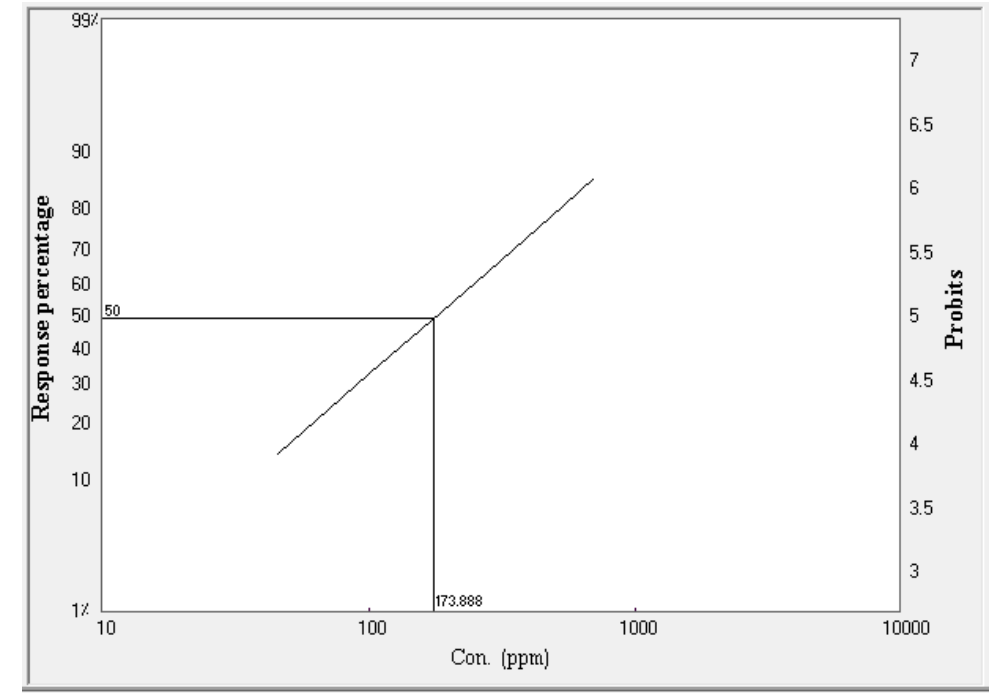

Figure 4. Toxicity line of Chitin synthesis inhibitor; nomolt against 4th larval instar of A. ipsilon after $72 \mathrm{~h}$ from treatment.

Table 1. Chitinase activity in $4^{\text {th }}$ larval instar of $A$. ipsilon after treatment with $\mathrm{LC}_{50}$ of nomolt.

\begin{tabular}{|c|c|c|}
\hline & Intermolting period & Molting period \\
\hline Control & $11.28 \pm 0.94^{\mathrm{a}}$ & $108.1 \pm 5.36^{\mathrm{a}}$ \\
\hline Treated & $12.41 \pm 0.75^{\mathrm{a}}$ & $98.61 \pm 6.30^{\mathrm{a}}$ \\
\hline
\end{tabular}

- Data are presented as the means $\pm \mathrm{SE}$

- Enzyme activity expressed as U/mg of protein.

- Means, within column, are insignificant different ( $P<0.01$, ANOVA).

Insect growth and development morphogonsis are dependent on the capability to remodel structures that containing chitin. Therefore, insects frequently produce chitin synthesis and chitinolytic enzymes. Balance between chitin synthesis and its degradation 
requires strict control of the participating enzymes during insect development (Merzendorfer \& Zimoch, 2003).

The obtained results showed that larval chitinase is activated before ecdysis, and the activity sharply decreased after molting is completed. In the silkworm, Bombyx mori, chitinase activity is not observed before apolysis, it is secreted before ecdysis (Koga et al., 1989) and its activity decreased sharply at ecdysis (Jeuniaux, 1961). Northern blots analysis revealed that transcripts of chitinase from the spruce budworm, Christoneura fumiferana appeared before each molt and peaked on the day of ecdysis from the second instar to the pupal stage but disappeared immediately after the molt (Zheng et al., 2002).

This work emphasizes that appearance of chitinase activity, in larvae is restricted to molting period, and prior to it, chitinase showed traces of activity suggesting that the main function of larval chitinase is the digestion of old cuticle. On the other hand, larval chitinase activity is rhythmic, and unlike to other enzymes such as esterases that have continuous activity at any given time. Future studies concerned with factors affecting chitinase activity must take into consideration this fact i.e. precaution that the sampling time is critical.

In spite of, no molting occurred during pupal stage, chitinase in the black cutworm, A. ipsilon pupae was much higher than that of larvae. Our results are in line with previous report by (Kawazu et al.,1996) who prepared a stable chitinase solution from $S$. litura pupae. In pupae, there are intensive physiological processes important for transformation to adult stage, and chitinase may participate in these process (Amin, 1998). Chitinolytic enzymes may catabolized glycolipids or glycoproteins substrates as reported previously (Koga et al.,1983).

Insects repeatedly produce chitinolytic enzymes in different tissues (Merzendorfer \& Zimoch, 2003). As shown in A. ipsilon larvae used in this study, major chitinase activity during molting period was retained in integument followed by alimentary control, but hemolymph and fat tissues had relatively very low activities. The results suggest that blood plays minor role in transporting the chitinase enzyme, and chitinase is localized in the integument. Our results further supported by Koga et al. (1992) who revealed that chitinase are synthesized in M. sexta and B. mori integuments as zymogens, which are activated by limited proteolysis. Amin (1998), reported that the presence of chitinases in integument can be explained by the hypodermis secretion of molting fluid into the space between new and old cuticles, which contains hydrolytic enzymes including chitinase.

Chitinolytic enzymes are products from cells in epidermis, gut, fat body or salivary glands in insects (Kramer \& Koga, 1986). The present results showed that 
chitinase activity in gut was higher than that found in hemolymph and fat tissues, probably due to the presence of chitinous membrane lining gut. The main function of chitinase is to digest the chitin contained in tissues such as the cuticle and gut lining during molting (Zhang et al., 2012).

In the present study the control larvae, appreciable chitinase activity appears only during molting period of the black cutworm larvae. Larvae treated with $\mathrm{LC}_{50}$ of nomolt followed this rule. This means that treatment did not cause any change in chitinase activity during intermolting or molting period. This led to assumption that mode of action of nomolt is not by activation of chitinase that leads to activation of chitin degradation, but nomolt acts by inhibition of chitin synthesis. These result are in line with Clarke \& Jewess (1990) who showed that chitin synthesis in S. littoralis was inhibited by teflubenzuron after $24 \mathrm{~h}$ post topical application of pesticide. Also Kale (2014) revealed that, Chitin synthesis inhibitors (CSI) block the production and formation of chitin. Because moulting must take place for the insect to reach the adult stage, a CSI poisoned insect can't make chitin, moult and can't reproduce thus eventually dies.

On the other hand, treatment by CSI's in some cases led to hyperchitinase activity. Yu \& Terrier (1977) explained the increased chitinase activity by the reduced activity of B-ecdysone metabolizing enzymes, consequently B-ecdysone accumulation stimulated chitinase activity. Also Zheng et al. (2002) found that the 20hydroxyecdysone analog; (tebufenozide) induced expression of chitinase in the early stage of the sixth instar of the spruce budworm, C. fumiferona and caused a precocious and incomplete molt. Furthermore chitinase activity was increased in moderate percentage (23.66\%) after treatment of newly hatched larvae $P$. gossypiella with LC 50 of teflubenzuron as compared to control (Rashad et al., 2015).

Finally, it could be suggested that importance of chitinase, in larvae, is restricted to molting process, while in pupae, it plays other physiological roles, and nomolt acts by inhibition of chitin synthesis not by enhancing of chitin degradation.

\section{REFERENCES}

1. Abbott, W. S. 1925. A method of computing the effectiveness of an insecticide. J. Econ. Entomol., 18, 265-267.

2. Abo El-Ghar, G. E. S., Khalil, M. S., and Eid, T. M. 1994. Effects of plant extracts on development and fecundity of Agrotis ipsilon (Lepidoptera: Noctuidae). Bull. Ent. Soc. Egypt, Econ. Ser., 21, 171-190.

3. Amin, T. R. 1998. Biochemical and physiological studies of some insect growth regulators on the cotton leafworm, Spodoptera littoralis (Boisd.). . College of Science, Ph.D. Thesis. 
4. Bade, M. L., and A. Stinson. 1981. Biochemistry of insect differentiation. A system for studying the mechanism of chitinase activity in vitro. Arch Biochem Biophys, 206(1), 213-221.

5. Clarke, L., and P. J. Jewess. 1990. The inhibitions of chitin synthesis in Spodoptera littoralis larvae by flufenoxuron, teflubenzuron and diflubenzueron. Pestic. Biochem., 28, 377-388.

6. Finney D.J. 1971. Propit analysis $3^{\text {rd }}$ Ed. Cambridge Univ. Press, London, pp:318.

7. Ghareeb, Iman, M.A. 2009. Physiological studies on some chitinolytic fungi and their role in control of seeds insects. M.Sc. Thesis, Fac. Sci., Zagazig Univ.

8. Ishaaya, I., and J. E. Casida. 1974. Dietary TH-6040 alters composition and enzyme activity of housefly larval cuticle. Pestic. Biochem. Physiol., 4, 484-490.

9. Jeuniaux, C. 1961. Chitinase: an addition to the list of hydrolases in the digestive tract of vertebrates. Nature, 192, 135-136.

10. Kale, B. 2014. A review on organophosphorus toxicity in the farmers of solapur district from India. International Journal of Biological Research, 2 (2), 69-77.

11. Kawazu, K.; S. Ohnish; H. Kanzaki and A. Kobayashi. 1996. A stable crude chitinase solution from Spodoptera litura pupae and a search for its inhibitors. $Z$. Naturforsch, 51c, 738-742.

12. Koga, D.; H. Fujimoto, T. Funakoshi, T. Utsumi and I. Ide. 1989. Appearance of chitinolytic enzymes in integument of Bombyx mori during the larval-pupal transformation. Evidence for zymogenic forms. Insect Biochem., 19, 123-128.

13. Koga, D.; T. Funkoshi, K. Mizuki, A. Ide, J. Kramer, K. Zen, H. Cho and S. Muthkrishman. 1992. Immunoblot analysis of chitinolytic enzymes in integument and molting fluid of the silkworm, Bombyx mori, and the tobacco harmworm, Manduca sexta. Insect Biochem. Molec. Biol., 22, 305-311.

14. Koga, D., J. Jillka and K. Kramer. 1983. Insect endochitinases: glycolproteases from moulting fluid, integument and pupal haemolymph. Insect Biochem., 13, 295-305.

15. Kramer, K. J., and D. Koga. 1986. Insect chitin: Physical state, synthesis, degradation and metabolic regulation. Insect. Biochem., 16, 851-877.

16. Kramer, K.J., and S. Muthukrishana. 1997. Insect chitinases : Molecular biology and potential use as biopesticides. Insect Biochem. Molec. Biol., 27: 887-900.

17. Mayer, R. T.; A. C. Chen and J. R. Deloach. 1981. Chitin synthesis inhibiting insect growth regulators do not inhibit chitin synthase. . Experimentia, 37, 337-338. 
18. Merzendorfer, H. and L. Zimoch. 2003. Chitin metabolism in insects: structure, function and regulation of chitin synthases and chitinases. J Exp Biol, 206(Pt 24), 4393-4412.

19. Post, L. C., B. J. Jong and W. Vincent. 1974. 1-(2,6-disubstituled benzolyl)-3phenylurea insecticides : Inhibitors of chitin synthesis. Pestic. Biochem. Physiol., 4, 473-483.

20. Qu, M.; L. Ma; P. Chen and Q. Yang. 2014. Proteomic analysis of insect molting fluid with a focus on enzymes involved in chitin degradation. J Proteome Res, 13(6), 2931-2940.

21. Rashad, A. M.; E. F. El-Khayat; T. R. Abd-El Zaher; A. M. Shams El-Din and H. S. Salim. 2015. Biochemical Studies of Some Pesticidal Formulations against Pectinophora gossypiella (Saunders) (Lepidoptera: Gelechiidae). J. Agric. \& Environ. Sci., 15(3), 303-307.

22. Singh, G., A. ; J. S. Bhalla; S. Bhatti; A. Chandel; A. Rajput; W. Abdullah; Andrabi, and P. Kaur. 2014. Potential of chitinases as biopesticides against agriculturally harmful fungi and insects. J. Microbial Biotechnol., 3, 27-32.

23. Waterhouse, D. F.; R. H. Hockman and J. W. Mckellar. 1961. An investigation of chitinase activity in cockroach and termite extract. J. Insect Physiol., 6, 96-112.

24. Yu, S. J., and L. C. Terrier. 1977. Ecdysone metabolism by soluble enzymes from the three species of Diptera and its inhibition by the insect growth regulator $\mathrm{TH}$ 6040. Pestic. Biochem. Physiol., 7, 48-55.

25. Zhang, D.; J. Chen; Q. Yao; Z. Pan; J. Chen and W. Zhang. 2012. Functional analysis of two chitinase genes during the pupation and eclosion stages of the beet armyworm Spodoptera exigua by RNA interference. Arch Insect Biochem Physiol, 79(4-5), 220-234.

26. Zheng, Y.; S. Zheng; X. Cheng; T. Ladd; E. J. Lingohr; P. J. Krell; B. M. Arif; A. Retnakaran and Q. Feng. 2002. A molt-associated chitinase cDNA from the spruce budworm, Choristoneura fumiferana. Insect Biochem Mol Biol, 32(12), 1813-1823.

27. Zhu, Q.; Y. He; J. Yao; Y. Liu; L.Tao and Q. Hung. 2011. Effects of sublethal concentrations of the chitin synthesis inhibitor, hexaflumuron, on the development and haemolymph physiology of the cutworm, Spodoptera litura. J. Insect. Sci., 12, $1-13$. 


\section{أنزيم الكيتينيز: مكان وجوده ، معدل نشاطه وتغير اته بعد المعاملة بمبيا}

\section{النومولت في الدودة القارضة}

\section{عزيزة حسن محمدي' ، طارق رئيس أمين}

$$
\begin{aligned}
& \text { ا ـ الدعمل المركزي للمبيدات، مركز البحوث الزراعية ، الدقي }
\end{aligned}
$$

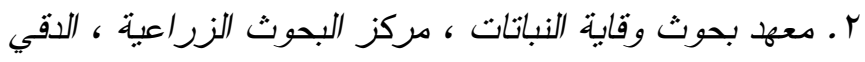

تم درسة أنزيم الكيتنيز كنوع من الأنزيمات المحلله للكيتين الداخلية الأفراز في الطور

البرقي الرابع للاودة القارضة السوداء، للكثف عن بعض خصائصه الفسيولوجية. و أظهرت النتائج أن نشاط الكيتينيز كان منخفضا حتى 1/ 1 ساعة قبل الانسلاخ إلى الطور اليرقى الر ابع، ولكن بدأ

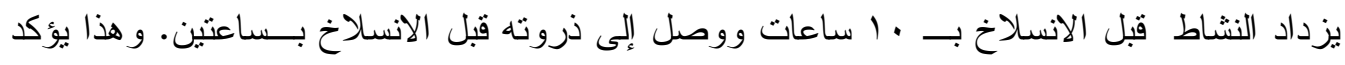

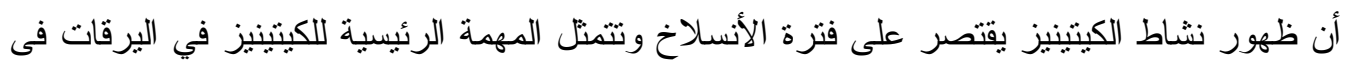

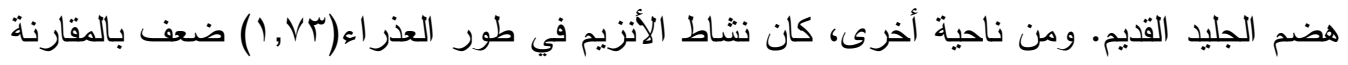

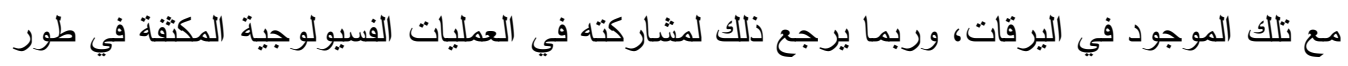

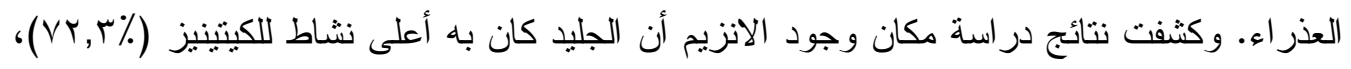
في حين أن الهيمولينف أظهر به أدنى نشاط للانزيم (9 (1)). وبالتالي، فإننا نستتنج أن الهيمولينف

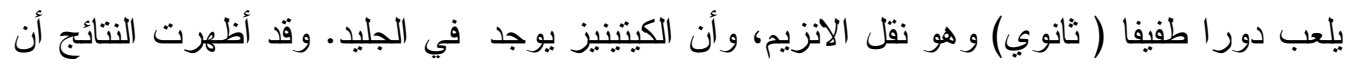

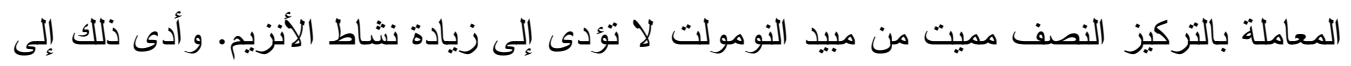
افتراض أن النومولت يعمل عن طريق تنبيط تخليق الكيتين وليس عن طريق زيادة هدم وتحلل

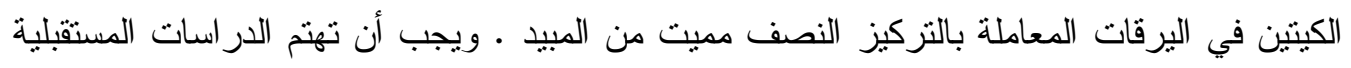
بالعو امل المؤثرة على نشاط الكيتينيز وأن يؤخذ بعين الاعتبار أن وقت أخذ العينات أمر بالغ الأهمية. 